\title{
CLINICAL FEATURES AND RISK FACTORS OF ABORTION IN PORT-SAID CITY
}

\author{
Nermen awad atia, Prof. Sanaa Ali Nour, Dr. Manar Fathy Heeba \\ B. Sc of Nursing suez canal university, Professor of Obstetrics and gynecolog \\ ical Nursing, Faculty of Nursing Port Said University Faculty of Nursing Zagazig \\ University, Lecturer of Maternity, Obstetrics and Gynecological Nursing
}

\begin{abstract}
Background: Abortion is a public health concern because of its impact on maternal morbidity and mortality. Aim of this study was to explore the clinical features of abortion and to identify the risk factors associated with abortion in Port Said City. Setting: It was carried out at the Obstetrics and Gynecology Department in Port Said and Port Fouad General Hospitals. Subjects: 400 women were included in the study, 200 were diagnosed as having abortion and 200 women had normal delivery. Data were collected using an interviewing schedule with questions about demographics and specific items regarding abortion history. Information included age, literacy, gravidity, abortion, type of abortion, family history of abortion, women life style, and the profile of patients who underwent abortion. The results of this study showed that abortion was more common among younger women (38.5\%) and older age group (5.5\%) as well as women exposed to hard physical work (31.3\%), long exposure to computer $(61.5 \%)$ and electromagnetic waves (19,5\%). Missed abortion (37,0\%) and induced abortion $(18,0 \%)$ were the most common types . It was concluded that aborted women were more common of the younger age group. Complete, missed and induced abortions were the most common types. The study recommended that the maternity nurse should be alert for early detection and identification of risk factors for abortion. Unwanted pregnancies must always be given the highest priority, and all attempts should be made to eliminate the need for abortion
\end{abstract}




\section{INTRODUCTION}

The word abortion derives from the Latin aboriri-to miscarry. According to the New Shorter Oxford Dictionary (2002), abortion is premature birth before a live birth is possible, and in this sense it is synonymous with miscarriage. It also means an induced pregnancy termination to destroy the fetus. Although both terms are used interchangeably in a medical context, popular use of the word abortion by lay persons implies a deliberate pregnancy termination (Willium, 2012). Spontaneous abortion occurs in an estimated $5-15 \%$ of pregnancies. Globally, abortion mortality accounts for at least $13.0 \%$ of all maternal mortality. New estimates are that 50 million induced abortions are performed each year in developing countries, with approximately 20 million of these performed unsafely because they are performed by persons without the proper skills or outside of a medically safe environment (Trupin, 2011) . More than 80 percent of spontaneous abortions are in the first 12 weeks and at least half result from chromosomal anomalies. It also appears to be a 1.5 male: female gender ratio in early abortuses (Benirschke and Kaufmann, 2000).

The risk for abortion is higher in women with a history of three or more previous abortions, couples with recurrent abortions have a 2-3\% incidence of parental chromosomal anomaly (i.e. balanced translocation), also maternal causes of abortion include structural abnormalities of the reproductive tract such as; congenital uterine defects (i.e. uterine septum), fibroids and cervical incompetence (Owen et al., 2003). Other causes of abortion include; maternal physical and psychological (stress factors) problems, hormonal factors and immune responses. One study suggests that the plasma of women with abortion contained significantly higher circulating levels of inflammatory markers as tumor necrosis factor alpha (TNF- $\alpha$ ), interferon gamma (IFN- $\gamma$ ), interleukin (IL)-6 and IL-10 than that of pregnant controls, irrespective of gestational age (Calleja-Agius et al., 2012).

\section{AIM OF STUDY:}

The aim of this study was to explore the clinical features of abortion and to identify the risk factors associated with abortion in Port Said City.

\section{SUBJECTS AND METHODS:}

\section{Research design:}

This study is an observation case-control study 


\section{Settings of the study:}

This study was conducted in the Obstetrics and Gynecology Department in Port Said and Port Fouad General Hospitals.

\section{Study population.}

The target populations included two groups:

\section{Group I or study group (aborted women):}

Two hundred women with a diagnosis of abortion were selected purposefully from the patients admitted to the Obstetrics and Gynecology Department, Port Said and Port Fouad General Hospitals.

\section{Group II or control group (non-aborted women):}

Two hundred parturient women were chosen by simple random selection from those admitted to labor unit at the Obstetrics and Gynecology Department, Port Said and Port Fouad General Hospitals

\section{Sample:}

The sample size was calculated according to the following equation:

$$
n=\frac{k \times 2 \sigma^{2}}{(M D)^{2}}
$$

Where $\sigma^{2}$ is the error variance, $M D$ is the minimum difference between groups and $k$ at the significance level $95 \%(\alpha=0.05)$ and power $80 \%(\beta=0.2)=7.8$.

Power calculations suggested that a minimum of 200 patients per group would detect a $20 \%$ difference between the groups $(\alpha=0.05, \beta=0.2)$

$\mathrm{n}=200$ women per group.

So, according to the calculations the sample size was 200 pregnant women within group I (aborted patients) and 200 pregnant women within group II (non-aborted patients)

\section{Technique of sample selection:}

\section{Tool for data collection}

An interview questionnaire form was used to collect relevant data about the study from patients and controls .

\section{Interview questionnaire:}


It included the following variables:

- Personal and demographic data: maternal age, residence, level of education, social class, history of consanguinity between mother and father.

○ Special habits: maternal or paternal smoking habits and caffeine

○ Occupational history: working hours, rate of work, heavy work, rest hours, occupational hazards (e.g. pesticides, x-rays or other radiations, dust, chemicals or biological exposure).

○ Obstetric history: gravidity, parity, abortion.

○ Menstrual history: rhythm, regularity, duration, last menstrual period (LMP).

○ Gynecological history: history of vaginal bleeding, abdominal pain, and passage of tissue with its onset, course, duration, amount, severity and associated symptoms.

○ History of chronic disease: heart disease, hypertension, diabetes mellitus, chronic kidney of hepatic diseases, autoimmune diseases and thyroid disorders.

○ History of maternal congenital uterine defects (particularly uterine septum), fibroids or cervical incompetence.

○ History of maternal infection (e.g. rubella virus, cytomegalovirus, Listeria infection or toxoplasmosis).

○ Family planning history

\section{Physical assessment sheet :}

Both general and local physical examinations were done for the patients and controls. Also, pelvic-abdominal ultra-sonography examination was done for aborted group to estimate the gestational age. The clinical diagnosis of abortion, causes, investigations required and treatment were all recorded by the researcher. Estimating the patient's hemodynamic stability and danger signal observed on patient's admission were recorded and reported by the researcher.

\section{Prognostic outcome measures:}

- Admission to intensive care unit (ICU).

- Amount of blood loss.

- Amount of blood transfusion.

- Performance of D\&C.

- Complications (fever, hypovolemic shock, DIC, maternal infection and cesarean hysterectomy).

- Duration of hospital stay and time of discharge from hospital. 


\section{Ethical Considerations:}

The purpose of the study and procedures to be performed were explained to the patients and controls, and oral consent to participate in the study was taken accordingly. All patients were managed properly after abortion. Post abortive hygiene and counseling about problems encountered and methods used to cope with these problems were discussed with every woman.

\section{RESULTS:}

Table(1): Concerning the causes of induced abortion and method used, genetic problem of fetus was the most common causes of induced abortion by the study group $(38.5 \%)$ followed by unwanted pregnancy $(33.2 \%)$. Meanwhile, vacuum aspiration was the most common method used for induced abortion (33.2\%) .

Table (2): It describes the clinical characteristics of current abortion. More than two thirds $(74.0 \%)$ of women in the aborted group were conscious. Meanwhile, in almost two thirds $(68.5 \%)$ bleeding amount was moderate and severe in (26.0\%) of cases.

Figure (1): Gestational age and type of abortion are presented. More than half of group was $>20$ week gestational age $(50.5 \%)$ and missed abortion was more common between types (37.0\%), tumor was highest cause of abortion (33.0\%).

Table (1): Distribution of the Aborted Group According to Causes of Induced Abortion and Method Used $(n=200)$.

\begin{tabular}{||l|l|l||}
\hline & No. & \% \\
\hline Causes of induced abortion $(\mathbf{n}=\mathbf{3 6})$ & 12 & 33.2 \\
Unwanted pregnancy & 14 & 38.5 \\
Genetic problem of fetus & 9 & 25 \\
Physical or psychological factor & 1 & 2.4 \\
Others & & \\
& 5 & 13.5 \\
Method used for induced abortion $(\mathbf{n}=\mathbf{3 6})$ & 3 & 8.2 \\
D\&c & 12 & 33.2 \\
Methotrexate & 8 & 22.1 \\
Vacuum aspiration & 8 & 22.1 \\
Dilation \& evacuation & 0 & 0 \\
Vaginal prostaglandin & & \\
Intraamniotic instillation. & & \\
\end{tabular}


Table 2: Distribution of the Studied Women According to Clinical Characteristics of Current Abortion ( $\mathrm{n}=200)$.

\begin{tabular}{||l|l|l||}
\hline Clinical Characteristics of Current Abortion & No & $\%$ \\
\hline $\begin{array}{l}\text { Level of consciousness }(\mathbf{n}=\mathbf{2 0 0}) \\
\text { Consciosness }\end{array}$ & 148 & 74.0 \\
$\quad$ Semiconscious & 49 & 24.5 \\
Unconscious & 3 & 1.5 \\
\hline Bleeding amount $(\mathbf{n}=\mathbf{2 0 0})$ & 23 & 11.5 \\
Mild & 137 & 68.5 \\
Moderate & 40 & 20.0 \\
$\quad$ Severe & & \\
\hline Bleeding days $(\mathbf{n}=\mathbf{2 0 0})$ & 73 & 36.5 \\
$\quad>5$ days & 127 & 63.5 \\
$\quad<5-10$ days or more & & \\
\hline Severity of bleeding $(\mathbf{n}=\mathbf{2 0 0})$ & 52 & 26.0 \\
Severe & 116 & 58.0 \\
Moderate & 32 & 16.0 \\
$\quad$ Mild & 126 & 63.0 \\
\hline Uterine size (n= 200) & 74 & 37.0 \\
$\quad$ Normal & 36 & \\
Abnormal & & 18.0 \\
\hline Cervical OS $(\mathbf{n}=\mathbf{2 0 0})$ & & \\
Closed & & \\
Opened & & \\
\hline
\end{tabular}

Distribution of the Aborted Group According to Gestational Age and 


\section{FIGURE 1:}

Types of Abortion $(n=200)$.

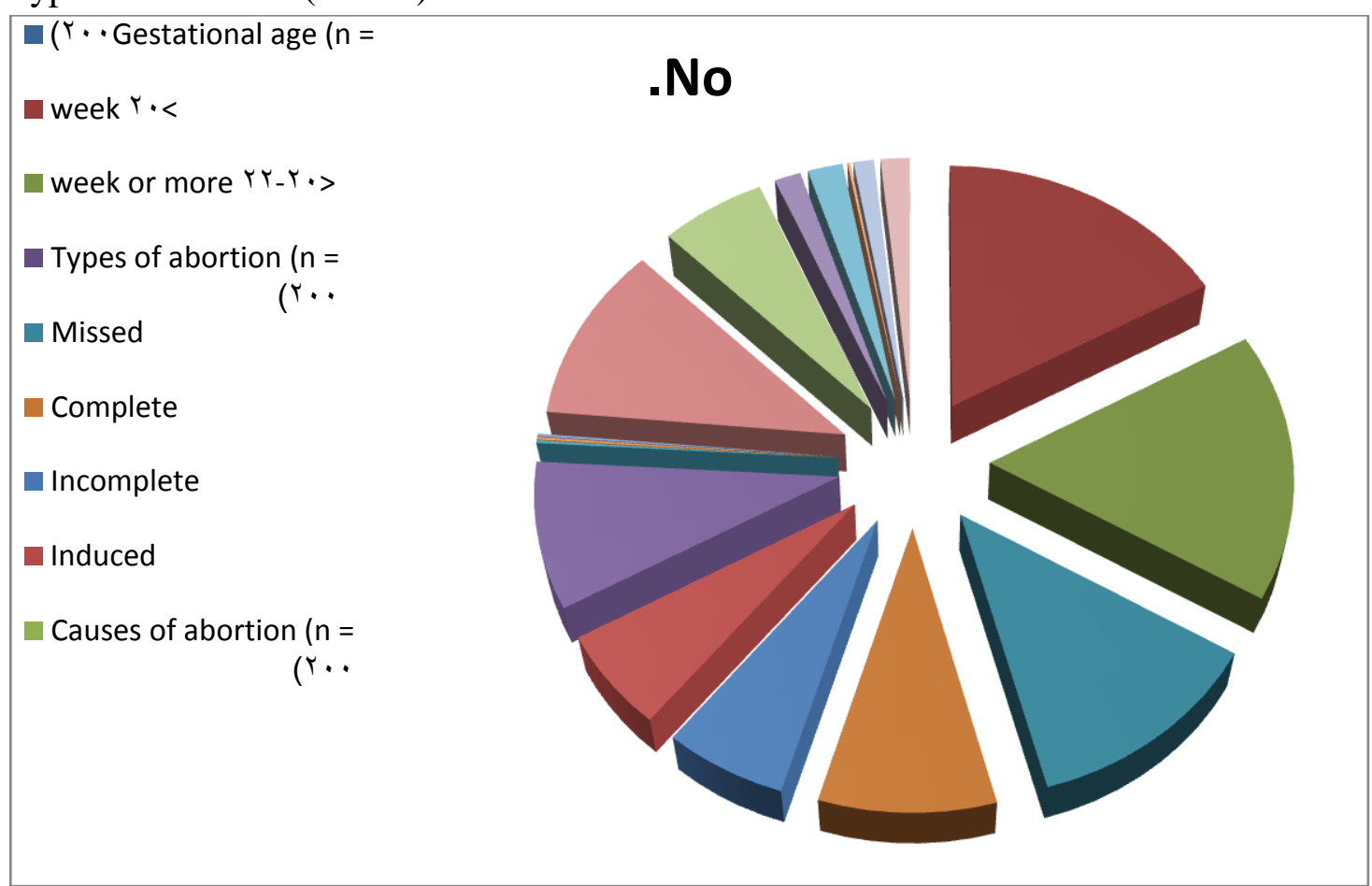

\section{DISCUSSION:}

The results indicate that abortion was significantly more common among the younger ( $<25$ years) women and older age group $(35+)$ compared to women with normal pregnancy. This corresponds well with the findings of Mohammad et al., (2011), study on in Al-AZhar University Hospital, Egypt, who reported that the risk of miscarriage was higher if the woman was aged $\geq 35$ years. Similarly, Nybo Andersen et al., (2000) studied the effect of maternal age on fetal loss and they found that fetal losses are increased after 35 years of age. More than one fifth of all pregnancies in 35year-old women resulted in fetal loss. Similarly, El-Shamandy (2007) in Assiut reported in his study about "a Study of post abortive complications among aborted women in EL- Minia city Hospitals" that, almost two thirds of aborted women were illiterate, and almost three quarters had low socioeconomic level.

Conversely, Pallikadavath and Stones (2006) studied the maternal and social factors associated with abortion in India in a population-based study. They found that the strongest predictor of abortion was maternal education. Women with at least a primary education were more likely than those with no education to have had an abortion (odds ratio=2.2). In agreement with the above study finding, Elias Senbeto, (2005) has shown the undeniable fact that the problem of abortion in general and induced 
abortion in particular is very high among the urban and rural women of their study areas.

Each year, approximately 20 million unsafe abortions are performed worldwide. They result in nearly 80,000 maternal deaths and hundreds of thousands of disabilities. In some countries, unsafe abortion is the most common cause of maternal death. It is also one of the most easily preventable and treatable condition. In many developing countries, giving attention and solving the problem of abortion is a low priority for the health service managers. Unsafe abortion is not only a medical problem but also a social problem. Different sectors should be involved in solving this problem (WHO,1995).

The stage of gestation when a woman presents for abortion is important since it determines the type of procedure that should be used and the risk of morbidity and mortality. The present finding is in accordance with that of (Kleinhaus et al,2006) who reported that most miscarriages occur so early in the pregnancy that the woman is not even aware that she was pregnant. More than 80 percent of abortions occur within the first 12 weeks of gestation.

Abortion becomes much less common by the end of the first trimester, and its incidence decreases successively thereafter. Overall, spontaneous loss in the second trimester is estimated at 1.5 to 3 percent, and after 16 weeks, it is only 1 percent (Simpson et al., 2007). Several studies describe that women have symptoms of depression after miscarriage; the same finding is reported in the present study. (Moulder, (1994) found that the majority of women have an intensive period of grieving, guilt, and anxiety after miscarriage. Women feel responsible for their miscarriages and have feelings of guilt, more than two thirds of women have guilt reactions. Miscarriage represents the loss of a pregnancy, of a baby or future child, of motherhood, of self-esteem and it may also engender doubts regarding ability to reproduce (Friedman, 1989; Lee \& Slade, 1996; Moulder, 1999). Feelings of emptiness, shame, helplessness and low self-esteem are commonly expressed after miscarriage (Frost \& Condon, 1996).

\section{CONCLUSION:}

\section{Based on the findings of the present study it can be concluded that :}

Many risk factors are associated with abortion. Some of these are related to sociodemographic, work, environmental, and life style factors of pregnant mother. The most important of these are age, educational level, and physical exposure at work, 
drinking coffee, tea, and nutrition during pregnancy. Other factors are related to menstrual, obstetric, and family and past history.

\section{RECOMMENDATIONS:}

Based on the most important findings of the study, the following recommendations are suggested: Prevention of unwanted pregnancies must always be given the highest priority and all attempts should be made to eliminate the need for abortion.

Risk factors of abortion play an important role, thus the maternity nurse should be alert for early detection and identification of these factors in order to reduce maternal and fetal death or complications. Initiation of strict control of these risks should be reinforced prior to conception, and such control should be maintained throughout pregnancy to reduce the incidence of complications.

\section{REFERENCES:}

Benirschke K and Kaufmann P (2000): Pathology of the Human Placenta, 4th ed . New York, Springer-Verlag.

Calleja-Agius J, Jauniaux $E$ and Pizzey AR (2012): Investigation of systemic inflammatory response in first trimester pregnancy failure. Hum Reprod Feb; 27(2):349-57.

Elias Senbeto, Getu Degu Alene, Nuru Abesno and Hailu Yeneneh (2005): [Ethiop J Health Dev.;19(1) 37-44]

Frost $M$ and Condon JT (1996): The psychological sequelae of miscarriage: a critical review of the literature. Aust N Z J Psychiatry; 30: 54-62.

Kleinhaus K, Perrin M, and Friedlander Y,(2006): Paternal age and spontaneous abortion. Obstet Gynecol 108:369

Mohammad KL, Ghazaly MM and Zaalouk TK (2011): Maternal brucellosis and human pregnancy. J Egypt Soc Parasitol 41(2):485,.

Moulder C (1994): Towards a preliminary framework for understanding pregnancy loss. J Reprod Infant Psychol; 12: 65-67.

Nybo Andersen AM, Wohlfahrt J, Christens P, Olsen J and Melbye M (2000): Maternal age and fetal loss: population based register linkage study. BMJ; 320: 17081712 .

Owen J, Iams JD and Hauth JC(2003). Vaginal sonography and cervical incompetence. Am J Obstet Gynecol; 188: 586. 
Pallikadavath S and Stones WR(2006): Maternal and Social Factors Associated with Abortion in India: A Population-Based Study. International Family Planning Perspectives, 32(3):120-125.

Simpson JL(2007): Causes of fetal wastage. Clin Obstet Gynecol; 50(1):10.

Williams Z(2012): Inducing tolerance to pregnancy. N Engl J Med; 367(12):1159. 


\section{المظاهر الإكلينيكية وعوامل الخطورة في الإجهاض بمدينة بورسعيد}

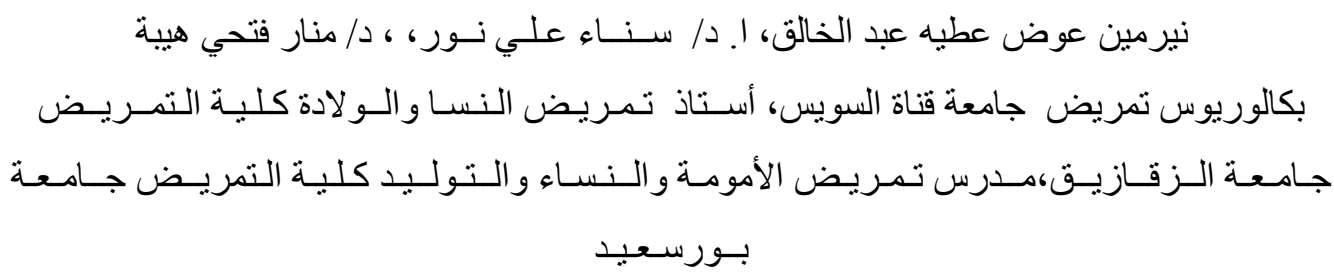

\section{الخلاصة}

الإجهاض هو مصدر قلق للصحة العامة بسبب نأثثر ها على مر اضة الأمهات و الوفيات. و الهدف من هذه الدر اسة هوستكثاف المظاهر الاكلينيكيه للإجهاض وتحديد عوامل الخطر المرتبطة بالإجهاض في مدينة بورسعيد تم تنفيذه في قسم أمر اض النساء والتوليد في بور سعيد وبور فؤاد بالمستشفيات العامة، أدرجت 400 امرأة في الدراسة، تم تشخيص 200 حالة اجهاض و 200 امر أة بالو لادة الطبيعية. وقد تم جمع البيانات باستخدام جدول المقابلات مع أسئلة حول التركيبة السكانية وبنود محدة بشأن تاريخ الإجهاض. معلومات حول العمر، ومحو

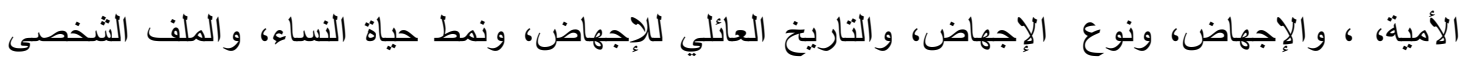

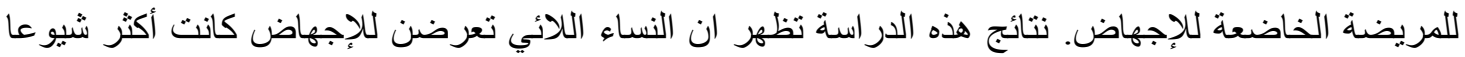
بين الثشابات (58.5٪) و الفئة العمرية الأكبر سنا (5.5٪). وكذللك النساء المعرضات إلى العمل الثـاق (31.3٪)، التعرض الطويل للكمبيوتر (61.5 \%) و الموجات الكهرومغناطيسية وكانت (5،19٪). كان الإجهاض الغائب (0،37٪) و الإجهاض المتعد (0،18\%) الأنواع الأكثر شيوعا. وخلص إلى أن المرأة المجهذة كانت أكثر

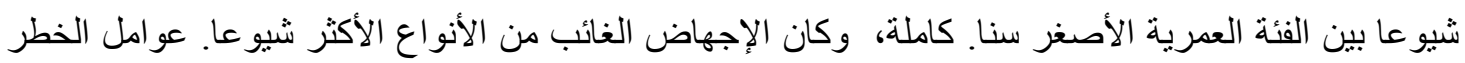

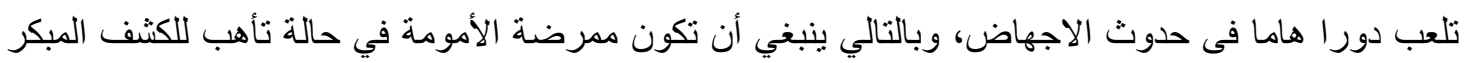
وتحديد هذه العوامل والحمل غبر المرغوب فيه ويجب دائما أن تعطى أولوية قصوى و بذل كل المحاولات لهات للقضاء على الحاجة للإجهاض . 